\title{
The Effect Of Climate Change On The Communities Of Ogbaru Wetland Of South West Anambra State, Nigeria
}

\author{
EzenwajiE.E. ${ }^{1}$ OrjiM.U. ${ }^{2}$ EneteC.I. ${ }^{3}$ Otti, V. I. ${ }^{4}$ \\ ${ }^{1,3}$ Department of Geography and Meteorology NnamdiAzikiwe University, Awka, Nigeria. \\ ${ }^{2}$ Department of Applied Microbiology and Brewing, NnamdiAzikiwe University, Awka, Nigeria. \\ ${ }^{4}$ Department of Civil Engineering Federal Polytechnic, Oko, Nigeria.
}

\begin{abstract}
The aim of this study was to examine the effects of climate change on the livelihood of the inhabitants of the communities in Ogbaru wetland of Anambra State, Nigeria. A total of 300 questionnaires dealing on the effects of climate change in the 16 communities of the area were designed and served on the inhabitants through stratified sampling technique for 3 months May - July 2011. Also 40 years meteorological data on temperature, rainfall and relative humidity of the area were sourced from NIMET synoptic station in the area. Data were analysed with the use of Multiple Regression Techniqueto ascertain the collective contributions of the meteorological elements to climate change in the area. Furthermore, cluster analysis was employed to agglomerate the 16 communities into defined groups. Result shows that the three meteorological elements namely Temperature, Rainfall and Relative Humidity, altogether contributed $43 \%$ to the overall variation in climate change of the wetland while cluster analysis grouped the 16 communities into three, according to the degree of the impact of climate change on them. Measures aimed at adapting to the adverse impact of the change such as creation of earth dams around the farms, use of markings on walls to gauge the flood height of previous years, employing adequate construction techniques in road construction in the area etc. were discussed.
\end{abstract}

Keywords: - Climate, NIMET, agglomerate, meteorological, variation, synoptic.

\section{INTRODUCTION}

The effect of climate change to the global environment has dominated many internationalconferences, workshops and fora. Meanwhilestudies of the effects of climate change have been carried out in many specific sectors of Nigeria. Aondover(1997), Ezenwaji(2010), and Nnaji(2011) investigated the influence of the phenomenon on water supply, whileAdejuwon (2006) and SEI (2008) have all studied the effect of climate change on agricultural and food production. Various implications of climate change on socio-economic development of Nigeria have been assessed (Abatam, 2007; Ugwuanyi and Anekeje, 2009). Its effects on urban and rural environments have also been studied (Uyigue and Agbo, 2007).

The natural resources of the Nigerian wetlands are indeed a major source of livelihood activity to wetlands inhabitants, while the nutrient rich soils are excellent for agricultural purposes. Climate variability and other human activities now threaten this unique habitat.Global temperature increases and causes the rise of the sea level, destroying coastal wetlands and drying up inland wetland basins that previously sustain human socioeconomic activities. The environment of inland wetland which is the focus of this paper, has maintained biodiversity by providing critically important habitat to a wide range of wild life species. Flood protection is one important role which wetlands are known to play. Inland wetland soilsact as natural sponges that trap and slowly release surface water. Wetlandvegetation also helps to slow the speed of floodwaters and distribute them more gradually over the floodplain. The adverse impact of climate change on the agricultural and human activities of the wetland areas of the country need to be ameliorated through adaptive measures. Apart from the works of Ozor and Umehai (2010) and that of Ezenwaji (2010), the study of the effect of climate change in the Nigerian wetland is scanty. This paper, therefore, seeks to study the effect of climate change on the Ogbaru wetland of Anambra State and suggest adaptive management measures in dealing with the identified effects.

\section{MATERIALS AND METHODS}

Study Area

The entire Ogbaru Local Government Area which constitutes a large wetland zone is located in the south western part of Anambra State, and lies between latitudes $5^{\circ} 42^{\prime}$ and $6^{\circ} 08^{\prime} \mathrm{N}$ and Longitudes $6^{\circ}, 42^{\prime}$ and $6^{\circ} 50 \mathrm{E}$. It is bound in the North by Onitsha South Local Government Area, in the east by Idemili South, Ekwusigo and Ihiala Local Government Areas, in the west by Delta State and in the south by Rivers and Imo States. The relief is a plain land of heightsranging from $0-50 \mathrm{~m}$ and characterized by swampy conditions as a result of its alluvial mud content. Its geology is mainly alluvium while the river Niger,and Ulasiriver which is its 
major tributary constitute the two major rivers in the area. However, thereare local creeks and ponds all over its landscape. The vegetation is a mixture of fringing forests along the banks of the river Niger and guinea savannah in the hinterland. The climate is hot wet equatorial with average maximum temperature of $30^{\circ} \mathrm{C}$ and the average minimum of $24^{\circ} \mathrm{C}$ depending on the season of the year.

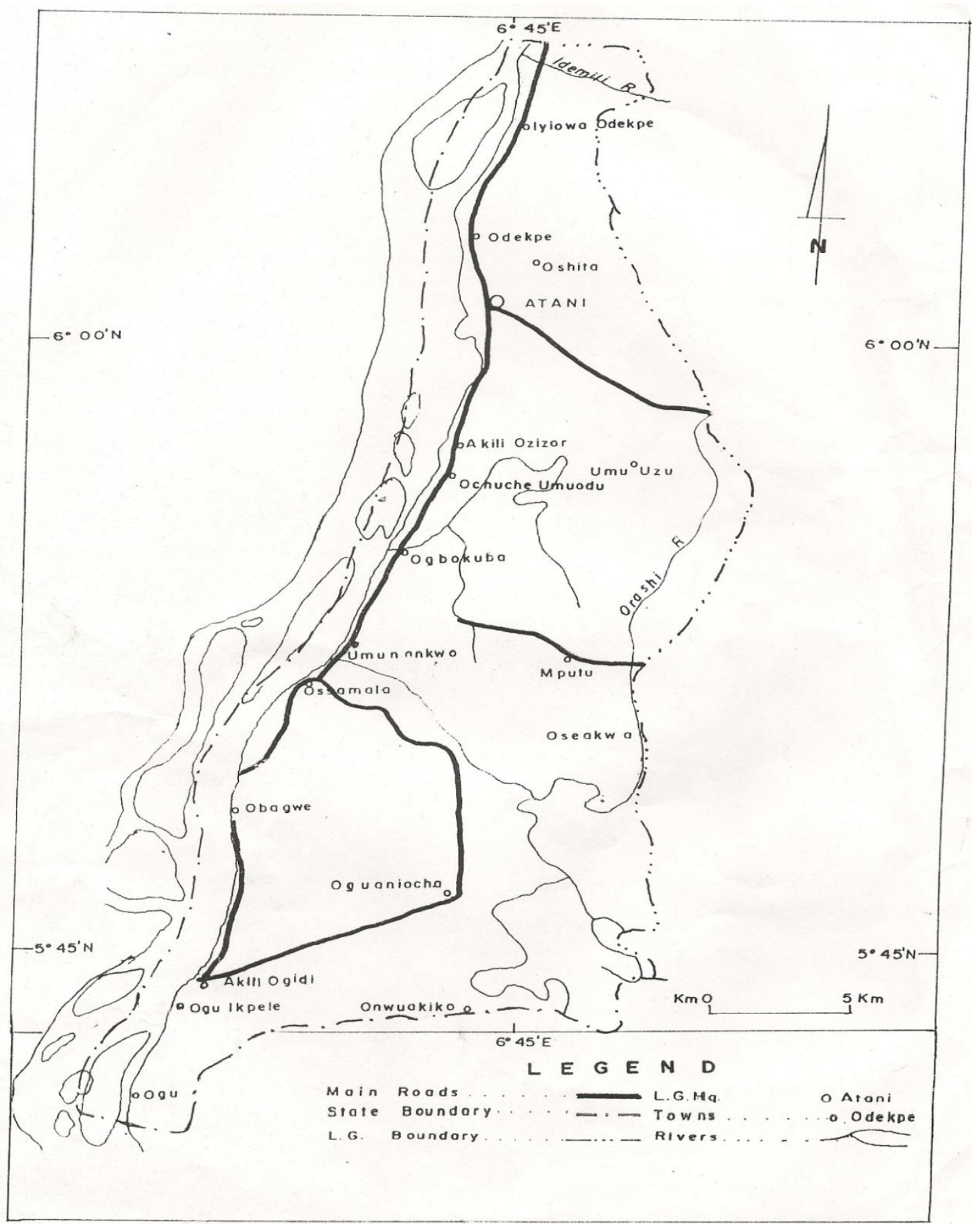

Figure 1: Map of Ogbaru Local Government Area.

Rainfall is experienced for 9 months of the year March - November, while dry season lasts from December to February (Monanu, 1975) with atotal annual figure about 1,900mm. A range of agricultural andhuman activities take place here and they include fishing, lumbering, crop production, water and land transport etc. The area has a total population of according to the recent population figure from National Population Commission (2006). Sixteen riparian communities are located in the study area. 


\section{Data Collection}

To ascertain the agricultural and human activities of the area affected by climate change, 300 questionnaires were designed and served on the inhabitants of the 16 communities that make up the area for 3 months (May - July) 2010, using stratified sampling technique with each community forming strata. Within each stratum, questionnaires were randomly distributed in proportion to the population of each community.In addition to the data collected from the questionnaires, the study also relied on temperature, rainfall and relative humidity data of the area for a period of 40 years, $(1971$ - 2010) sourced from the Nigerian Meteorological Agency, synoptic station, at Nkwelle, Onitsha, which is about $5 \mathrm{kms}$ to the study area. We took the data from this station as reliable because it is employed by government and other agencies to predict the meteorological elements for agricultural activities in the area.

\section{Data Analysis}

Data were analyzed with the use of Multiple Linear Regression to establish the contributions of the climate elements to the destruction of agricultural and human activities. The number of flood events in the area was used as the dependent variable, while the three climatic elements namely Temperature, Rainfall and relative Humidity were used as independent variable. (Table 1) Cluster Analytical Technique and Multiple Regression Analysis were employed in the study. The variables isolated from the questionnaire and from previous research in the area likeObidike(2006) were used to run cluster analysis and the resultrevealed a spatial arrangement of the effect of the variables on various communities in the area. Of all the methods ofcluster analysis, discussed by Koo et-al (2005) was used in this study because it minimizes the loss of data information.

\section{Results and Discussion}

The 40 year average of temperature, rainfall and relative humidity of the area are presented in Table 1 while the labelling and explanation of the variables are seen in Table 2.

Table 1: 40 year 1971 - 2010 Average Temperature, Rainfall and Relative Humidity togetherwith the number of major flood events in Ogbaru wetland

\begin{tabular}{|c|c|c|c|c|}
\hline Year & Temp $\left({ }^{\circ} \mathbf{C}\right)$ & Rainfall (mm) & $\begin{array}{l}\text { Relative Humidity } \\
(\%)\end{array}$ & $\begin{array}{l}\text { Numbers of major flood events } \\
*\end{array}$ \\
\hline 1971 & 29.4 & 1662 & 44.4 & 6 \\
\hline 1972 & 30.1 & 1612 & 49.2 & 4 \\
\hline 1973 & 28.2 & 1566 & 39.2 & 2 \\
\hline 1974 & 28.9 & 1633 & 46.9 & 4 \\
\hline 1975 & 27.3 & 1687 & 58.4 & 6 \\
\hline 1976 & 28.4 & 1849 & 56.8 & 5 \\
\hline 1977 & 28.9 & 1877 & 58.1 & 8 \\
\hline 1978 & 28.4 & 1820 & 62.3 & 8 \\
\hline 1979 & 27.9 & 1829 & 54.1 & 6 \\
\hline 1980 & 27.5 & 1864 & 59.3 & 6 \\
\hline 1981 & 27.2 & 1842 & 52.1 & 4 \\
\hline 1982 & 28.6 & 1872 & 60.1 & 5 \\
\hline 1983 & 26.9 & 1828 & 58.9 & 5 \\
\hline 1984 & 28.1 & 1794 & 54.6 & 3 \\
\hline 1985 & 26.3 & 1849 & 58.7 & 4 \\
\hline 1986 & 28.4 & 1812 & 65.4 & 9 \\
\hline 1987 & 28.5 & 1756 & 63.4 & 7 \\
\hline 1988 & 26.3 & 1791 & 64.1 & 6 \\
\hline 1989 & 26.9 & 1920 & 65.9 & 8 \\
\hline 1990 & 27.1 & 1846 & 64.1 & 7 \\
\hline 1991 & 28.7 & 1821 & 64.8 & 4 \\
\hline 1992 & 28.6 & 1920 & 65.7 & 4 \\
\hline 1993 & 28.4 & 1872 & 62.6 & 3 \\
\hline 1994 & 26.4 & 1856 & 68.3 & 4 \\
\hline 1995 & 28.6 & 1824 & 67.2 & 5 \\
\hline 1996 & 28.6 & 1881 & 66.4 & 2 \\
\hline 1997 & 27.4 & 1866 & 67.9 & 3 \\
\hline 1998 & 27.9 & 1846 & 67.8 & 4 \\
\hline 1999 & 27.4 & 1822 & 67.4 & 4 \\
\hline 2000 & 27.9 & 1814 & 68.3 & 4 \\
\hline 2001 & 28.7 & 1869 & 67.3 & 2 \\
\hline 2002 & 28.6 & 1881 & 67.4 & 3 \\
\hline
\end{tabular}




\begin{tabular}{|l|l|l|l|l|}
\hline 2003 & 28.1 & 1826 & 64.2 & 3 \\
\hline 2004 & 28.4 & 1883 & 65.1 & 5 \\
\hline 2005 & 27.3 & 1842 & 62.4 & 4 \\
\hline 2006 & 27.9 & 1809 & 64.1 & 3 \\
\hline 2007 & 27.7 & 1832 & 61.2 & 5 \\
\hline 2008 & 27.4 & 1881 & 66.2 & 6 \\
\hline 2009 & 28.2 & 1845 & 67.2 & 6 \\
\hline 2010 & 28.3 & 1861 & 68.1 & 7 \\
\hline
\end{tabular}

Source: Nigerian Meteorological Agency Amawbia Synoptic Station, (2011).

* Obidike (2006) and field work (2010).

Table 2: Parametisation of Variables of Climate Change Effects in OgbaruWetland

\begin{tabular}{|l|l|}
\hline Variable label & Explanation \\
\hline SWELL & Number of wells that swell up because of flooding in 2010 \\
\hline AGRIC & Number of Agric farms that were destroyed by flood in 2010 \\
\hline LOGG & Number of locations that were waterlogged for the entire rainy season \\
\hline POLL & $\begin{array}{l}\text { Number of water sources that were polluted with microbial contaminants from } \\
\text { floods in 2010 }\end{array}$ \\
\hline SILT & Number of streams that were silted in 2010 \\
\hline DISP & Number of families displaced in 2010 as a result of flooding \\
\hline FISH & Average price of fishes harvested in August 2010 \\
\hline DES & Number of roads destroyed by flooding and soil erosion in 2010 \\
\hline
\end{tabular}

Also Table 3 shows the data gathered from the above variables during the field work.

Table 3: Field Data of the Resultant Effect of the Three Climatic Elements

\begin{tabular}{|l|l|l|l|l|l|l|l|l|l|}
\hline S/N & Community & SWELL & AGRIC & LOGG & POLL & SILT & DISP & FISH & DES \\
\hline 1 & Okpoko & 64 & 0 & 10 & 15 & 10 & 0 & 0 & 11 \\
\hline 2 & Odekpe & 32 & 4 & 16 & 14 & 8 & 6 & 600 & 2 \\
\hline 3 & Ohuta & 10 & 3 & 8 & 8 & 6 & 9 & 1000 & 2 \\
\hline 4 & Atani & 15 & 10 & 18 & 12 & 10 & 10 & 1000 & 2 \\
\hline 5 & AkiliOzizor & 20 & 6 & 9 & 14 & 14 & 12 & 1500 & 3 \\
\hline 6 & Umu-Uzu & 6 & 4 & 3 & 10 & 11 & 8 & 1500 & 2 \\
\hline 7 & Ochuche & 4 & 8 & 10 & 5 & 10 & 8 & 1500 & 3 \\
\hline 8 & Ogbakuba & 9 & 6 & 18 & 4 & 8 & 7 & 800 & 2 \\
\hline 9 & Umunankwo & 4 & 11 & 12 & 7 & 6 & 10 & 600 & 2 \\
\hline 10 & Osomala & 6 & 15 & 22 & 5 & 13 & 12 & 800 & 2 \\
\hline 11 & Obagwe & 4 & 13 & 6 & 2 & 4 & 6 & 1000 & 2 \\
\hline 12 & Oguaniocha & 8 & 22 & 16 & 10 & 10 & 8 & 1000 & 4 \\
\hline 13 & AkiliOgidi & 7 & 29 & 20 & 5 & 21 & 29 & 600 & 2 \\
\hline 14 & Ogulkpele & 4 & 18 & 20 & 4 & 10 & 28 & 2500 & 3 \\
\hline 15 & Mputu & 6 & 4 & 8 & 3 & 6 & 4 & 600 & 2 \\
\hline 16 & Umuodu & 3 & 6 & 4 & 5 & 8 & 4 & 600 & 3 \\
\hline
\end{tabular}

Data in Table 1 were analyzed using the Multiple Regression Analysis to determine the contributions of the climatic elements to the destruction of the agricultural and human activities of the area. The climatic elements were labelled as follows;

Variable

Temperature

Rainfall

Relative Humidity
Label

TEMP

RAIN

REHU

When the 3 climate elements (used as independent variables) were correlated on the number of flood events, (the dependent variable)it produced the result shown in Table 5. 
Table 5: Result of the Correlation Analysis

\begin{tabular}{|l|l|l|l|l|}
\hline Variables & Flood & Temp. & Rainfall & Humidity \\
\hline Flood & 1.000 & -0.74 & -0.108 & 0.085 \\
\hline Temp. & -0.074 & 1.000 & -0.318 & -0.275 \\
\hline Rainfall & 0.108 & -0.318 & 1.000 & $0.757^{*}$ \\
\hline Humidity & 0.085 & -0.275 & $0.757^{*}$ & 1.000 \\
\hline
\end{tabular}

* High correlation coefficients.

The correlation in Table5isgenerally low except for rainfall and atmospheric humidity. This is the natural trend as the higher the rainfall the more likely is relative humidity.Conversely, flood and all the parameters are weakly correlated but their various relationships are expected. For example the negative relationship between flood and temperature means that as temperature is reducing, flood is increasing because within that situation there are chances of increased rainfall. The result of the Regression Analysis (Table 6) indicates that the combined atmospheric parameters contributed $43 \%$ to flooding in the area. This means that anthropogenic and environmental factors take up 57\% of the flooding in the wetland. This is expected because of the influence of large body of water which supplies ample moisture during evaporation which eventually comes back to the environment as rain which floods the environment.

Table 6: Result of the Regression Analysis

\begin{tabular}{|l|l|l|l|}
\hline Model & $\mathbf{R}$ & $\mathbf{R}^{2}$ & Std. Error of estimate \\
\hline 1 & $116^{\mathrm{a}}$ & 0.043 & 1.837 \\
\hline
\end{tabular}

A predictors: (constant) Humidity, Temp, Rainfall.

The ANOVA performed to ascertain the strength of our regression shows that its p-level (sig) is 0.03 which is below0.05 level (Table 7).This indicates that the regression model is strong in interpreting the relationship between Flood and Climatic parameters.

Table 7: ANOVA Table

\begin{tabular}{|l|l|l|l|l|l|}
\hline Model & Sum of squares & Df & Mean square & F & Sig \\
\hline Regression & 1.646 & 3 & 0.549 & 0.163 & 0.03 \\
\hline Residual & 121.454 & 36 & 3.374 & & \\
\hline Total & 123.100 & 39 & & & \\
\hline
\end{tabular}

However, based on the field data generated for each of the 8 variables a clusteranalytical method earlier employedby Koo et-al(2005) was performed and the result shows the spatial impact of climate change on the 16 communities as produced by Cluster Analysis model in Figure 2, Table 8 however, shows the regionalization of the impact of climate change in the communities located within Ogbaru wetland.

\section{Dendrogram}

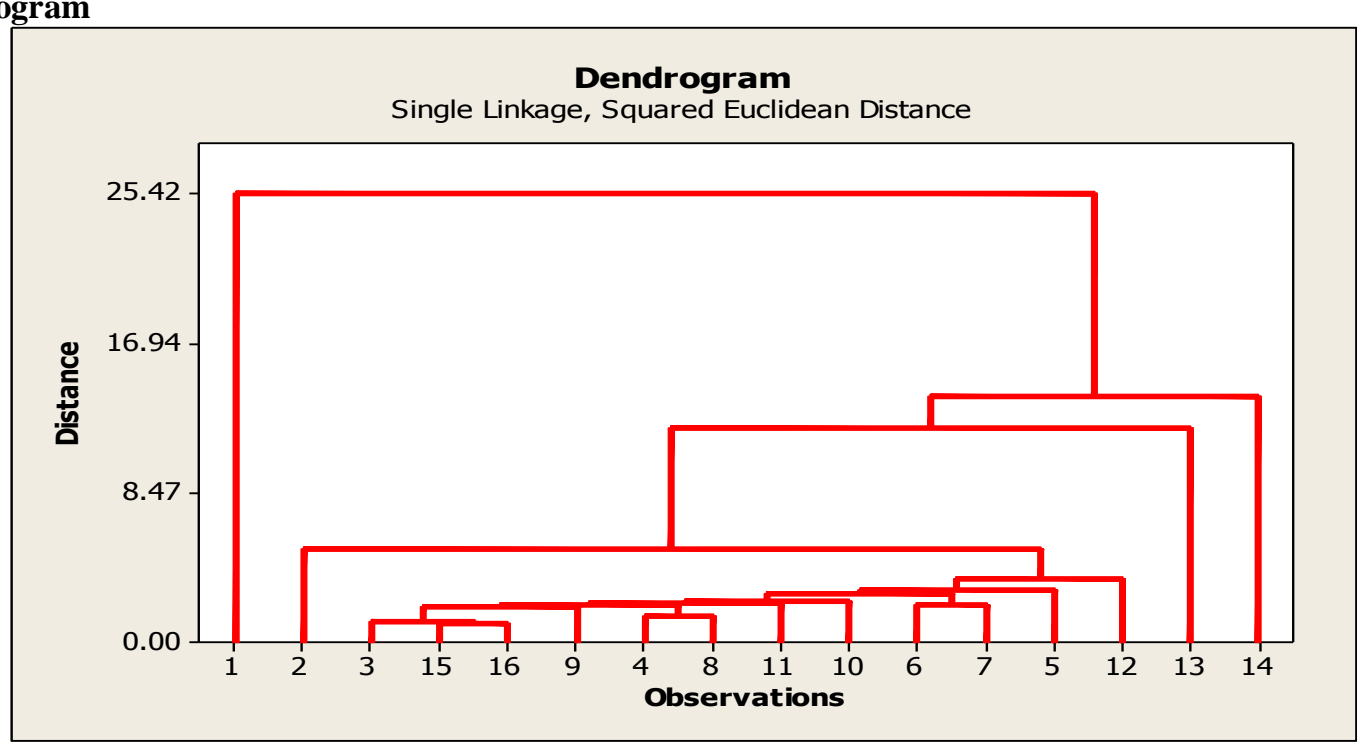

Fig. 2: The Dendogram of the area. 
From this figure, the area was organized by the model in a three group cluster as follows;

Table 8: Climatic Change impact similarities of Communities in Ogbaru

\begin{tabular}{|l|l|l|}
\hline Groups & Group features & Community and their identification number \\
\hline 1. & High climatic change impact & Okpoko (1) and Ogwuikpele (14) \\
\hline 2. & Moderate climate change impact & Odekpe (2) and AkiliOgidi (13) \\
\hline 3. & Low climatic change impact & $\begin{array}{l}\text { Ohital (3), Atani (4), AkiliOzizor (5), Umuzu (6), } \\
\text { Ochuche (7), Ogbakuba (8), Umunankwo (9), } \\
\end{array}$ \\
& & $\begin{array}{l}\text { Ossamala (10), Obegwe (11), Ogwuanocha (12), } \\
\text { Mputu (15) and Umuodu (16). }\end{array}$ \\
\hline
\end{tabular}

The cluster analysis has thus agglomerated the 16 communities into 3 groups based on the degrees of impact of climate change on them, viz;

Group 1 communities are those that are flooded for over 8 months of the year. Included here are Okpoko which in the urban area of the wetland. The high level of impervious covering, blocking of drainage systems and manifest absence of any type of vegetation in this area together with its very low lying relief may have accounted for this. Then Oguikpele which is another community in this group is also usually overran by flood for mostpart of the year at times up to 9 months. The main reason here is as a result of its low lying relief and its location at the point where the river Niger seem to have one of the greatest discharge rates. The overflow of the river bank by the water from the river into the overlying plain is therefore an essential geographical feature of this location.

Group 2 are two communities that have moderate climate change impact. As in group 1, here only two communities are included and they are Odekpe which has a considerable level of urbanization. The other community isAkiliOgidi which is very close to Oguikpele. All the factors that gave rise to high level of flood in okpoko and Oguikpele also account for the situation in these two communities.

Group 3are 12 communities that are classified as areas with low climate change impact. These are Ohita, Atani, AkiliOzizor, Umuzu, Ochuche, Ogbakuba, Umunankwo, Ossomala, Obegwe, Ogwuanocha, Mputu and Umuodu. Halfof the numbers of communities in this group are located at the river bank while the remaining half are located away from the banks. Those that are not located at the banks are Ohita, Atani, Umuzu, Umuodu, Mputu and Ogwuanochawhich always have less severe flood problems.

It could be indicated here that a whole range of agricultural and human activities are seriously affected by the flooding activities in the area. The generally low-lying nature of Ogbaru wetland makes it prone to flooding which destroy farmland, sack communities, cut road network, pollute rivers and water sources, reduce fish harvest and a number of other havocs. The following adaptation measures are suggested.

1. The inhabitants of the area have been practicing adaptation measures for ages which should now be urgently strengthened. From our fieldwork investigation, we observed that so many farms had earth dykes of small heights around their farms. Our enquiry revealed that they are built to avoid inflow of flood waters into their farms. In this regard, government should encourage the farmers with seed funds to help them continue with this practice.

2. The inhabitants make markings on the walls at the banks of river Niger to gauge the height of flood of the previous year and to know when a succeeding years flood has gone beyond that height, the inhabitation usual create marks at the banks of the river. This is indeed a warning signal to alert them as to when to move out of an area to another safe location. Although, this method seems crude, it, however, calls for an urgent action from relevant government agencies to increase efforts on flood forecastingin the area so as to alert the local people whenever there is an impending flood.

3. Again, because fishing activities are hampered by high volume of floods, the local people have been creating artificial fish holes in their farms from where they harvest fishes when floodsrecede usually at the end of flood episodes.During floods, fishes move into such holes as ready homes andfish farmers go there to harvest large quantities when the floods recede. In this regard, the government can help by creating artificial pondages at the flood plain where the fishes could find sanctuary during inclement flood period and harvest thereafter.

4. Recent road construction methods have not addressed the peculiar geographic nature of the area, leading to the incessant collapse of both tared and earth roads. It is suggested that any road construction of the area should ensure that enough stone base and drainages are provided to ensure that flood waters do not destroy them. 
5. Also in the part of the wetland that is already urbanized, all human activities that aid flooding should be avoided. In Okpoko area of the wetland, the level of flooding whenever it rains is frightening which calls for immediate urban planning measures.

\section{CONCLUSION}

Since a range of damages from future flood of the area is inevitable, efforts should be made to promote the adaptation measures outlined in this paper. It is indeed evident that the old adaptation strategies are no longer coping with the increasing menace of climate change in the area.Modern measures should therefore be adopted. The efforts of the State government and indeed other government agencies should be concentrated on areas with high flood prone risks such as Okpoko and Oguikpele.Finally it is envisaged that since we have achieved a categorization of degree of climate change impact in the area, all adaptation measures should be in response to the extent of the impact on the communities.

\section{REFERENCES}

[1] Abatam, A.A. (2007): Effect of Air Pollution on the Socio-Economic Development in Nigeriahttp://ihy2007.org/img/IHY, Nigeria Abatam.doc

[2] Adejuwon, I.O. (2006): "Food Crop Production in Nigeria II: Potential effects of climate change". Climatic Research, Vol. 32, pp 229-245.

[3] Anpdover, A.T. (1997): Droughts, Rainfall and Rural Water Supply in Northern Nigeria. PhD Thesis, Department of Geography, Mcmaster University.

[4] Ezenwaji, A.N. (2010). Flood Mitigation Parameters of Apiti Wetland Soil of Umuawulu, Awka South L.G.A., Anambra State. An Unpublished M.Sc. Thesis, Department of Zoology, NnamdiAzikiwe University, Awka.

[5] Ezenwaji, E.E. (2010): "Climate Change and Household Water Supply Shortages in Onitsha Urban Area, Nigeria" in AnyadikeR.N.C., Madu, I.A. and Ajaero, C.K. (eds), Climate Change and the Nigerian Environment, Jamoe Publishers, Enugu.

[6] Koo, J.Y., Yu, M.J., Kim, S.G., Shim, M.H., \& Koizumi, A. (2005): "Estimating Regional Water Demand in Seoul, South Korea, Using Principal Compound Analysis and Cluster Analysis". Water Science and Technology: Water Supply, Vol. 5, No. 1, pp 1-7.

[7] Monanu, P.C. (1975): "Rainfall" in OfomataG.E.K. (ed) Nigeria in Maps: Eastern States. Ethiopia Press Benin City.

[8] National Population Commission (2006): 2006 Local Government Area Population. Govt. Printer Abuja.

[9] Nnaji, A.O. (2011): "Implications of Recent Rainfall Variability for urban Water Supply and Sustenance in Owerri, Imo State". Paper delivered at the $1^{\text {st }}$ National Workshop of the Environment Development Initiative for Africa (edia) Awka, 24 $4^{\text {th }}-26^{\text {th }}$ August, 2011.

[10] Obidike, J. (2006). The Development of Ogbaru Area of Anambra State. Journal of Regional Development, Vol. 4, No. 3, pp $60-71$.

[11] Ozor, N. and Umehai, M.C. (2010): Effects of Climate Change on the Livelihoods of wetlands inhabitants in Nigeria. A Review, in AnyadikeR.N.C., Madu, I.A., and Ajaero, C.K. (eds.) Climate Change and the Nigerian Environment.

[12] SEI (2008): Climate Change and Adaptation to African Agriculture. Report prepared by Rockefeller Foundation by Stockholm Environment Initiative, March 2008, pp 54.

[13] Ugwuany, A.C. and Anekeje, B. (2009): "Increasing Climate Change effects on Humans Activities of some rural communities in Benue area, Nigeria". Journal of Continental Ecology, Vol. 2, No. 2, pp 75-87.

[14] Uyigue, E. andAgbo, M. (2007): "Coping with Climate Change and Environmental Degradation in the Niger Delta of Southern Nigeria. Community Research and Development Centre, Nigeria CREDC. 